IJMS 17 (1), 37-53 (2010)

\title{
SATISFYING CUSTOMERS USING TOTAL QUALITY MANAGEMENT: THE MEDIATING ROLE OF CONTROL SYSTEMS
}

\author{
ZULNAIDI YAACOB \\ OMMEI KOLSUM S. ROUTER \\ School of Distance Education \\ Universiti Sains Malaysia
}

\begin{abstract}
The premise of this paper is that Total Quality Management (TQM) must be adopted as a way of life for employees and not just as a slogan per se, so that the intended goal of implementing $T Q M$ can be fully realised. In order to internalise the philosophy of TQM into each organisational member, control systems play an important role. Control systems, among others, are implemented as systems for aligning the intended objectives of TQM and the individual objectives of each employee. The findings of this study supported the contingency theory that suggested the control systems being practised should be aligned with the strategy pursued to achieve the intended objectives. This paper extends the current existing knowledge by investigating the mediating role of control systems in explaining the relationship between TQM and customer satisfaction.
\end{abstract}

Keywords: Total quality management; control system.

\begin{abstract}
ABSTRAK
Premis makalah ini ialah Pengurusan Kualiti Menyeluruh (PKM) perlu diamalkan sebagai satu budaya hidup para pekerja dan bukan sebagai satu slogan sematamata. Untuk menjadikan PKM sebagai satu budaya hidup para pekerja, sistem kawalan memainkan peranan yang penting. Antara peranan sistem kawalan ialah memastikan matlamat PKM dan matlamat setiap individu dalam sesebuah organisasi adalah selari. Penemuan kajian ini menyokong Teori Kontigensi yang menyatakan bahawa sistem kawalan yang dilaksanakan perlu sesuai dengan strategi yang diamalkan supaya objektif pelaksanaan strategi dapat dicapai. Justeru kajian ini adalah signifikan pada literatur dengan mengkaji peranan sistem kawalan sebagai pemoderat dalam menjelaskan hubungan antara PKM dan kepuasan pelanggan.
\end{abstract}

Kata Kunci: Pengurusan kualiti menyeluruh; sistem kawalan. 


\section{Introduction}

The existence of local governments is to provide services that are needed by their constituents. However, the customers of local governments are not limited to their constituents. For instance, customers of local governments also involve businessmen, the central government, and other governmental institutions. Given this, the ability of local governments to fulfil reasonable expectations of their customers becomes crucial. Therefore, local governments worldwide have implemented Total Quality Management - (TQM) in their organisations since TQM has been widely recognised as a significant determinant of customer satisfaction.

TQM is not just a slogan per se, or just another management fad that can be completely implemented within a day or two. On the other hand, TQM should be viewed and understood as a culture that needs to be internalised by each organisational member, so that the real philosophy of TQM could be appreciated by the organisational members. The TQM related activities - like quality day, quality award, or displaying quality slogan should be encouraged as an impetus for the development of quality culture in an organisation, and not as an objective of TQM implementation. TQM itself should be looked as a means toward an end, and not as a destination.

Therefore, the premise of this paper is that TQM should be internalised into each organisational member, which can be guided by control systems, before the customer can be satisfied. After long years of investigating the direct relationship between TQM and various dimensions of performance, the literature has concluded that future researchers need to investigate the variables that could influence the effectiveness of TQM implementation (Ehigie \& McAndrew, 2005). Therefore, this study has investigated a structural relationship between TQM, strategic control systems, and customer performance.

\section{Theoretical Development}

\section{Research Framework and Hypotheses}

Contingency theory suggested that the design of control systems provides an implication on the process of executing the strategy of an organisation (Banker, Potter \& Schroeder, 1993). According to the framework of contingency research discussed by Moores and Chenhall (1994), the performance achieved is the function of the match between the contingent variable and control systems variable. The contingent variable, among others, is a strategy implemented by the organisation. They have concertedly agreed to the control systems variable as an intervening variable between

38 IJMS 17 (1), 37-53 (2010) 
the strategy and performance variables. Figure 1 depicts the initial research framework which is consistent with the framework of contingency research.
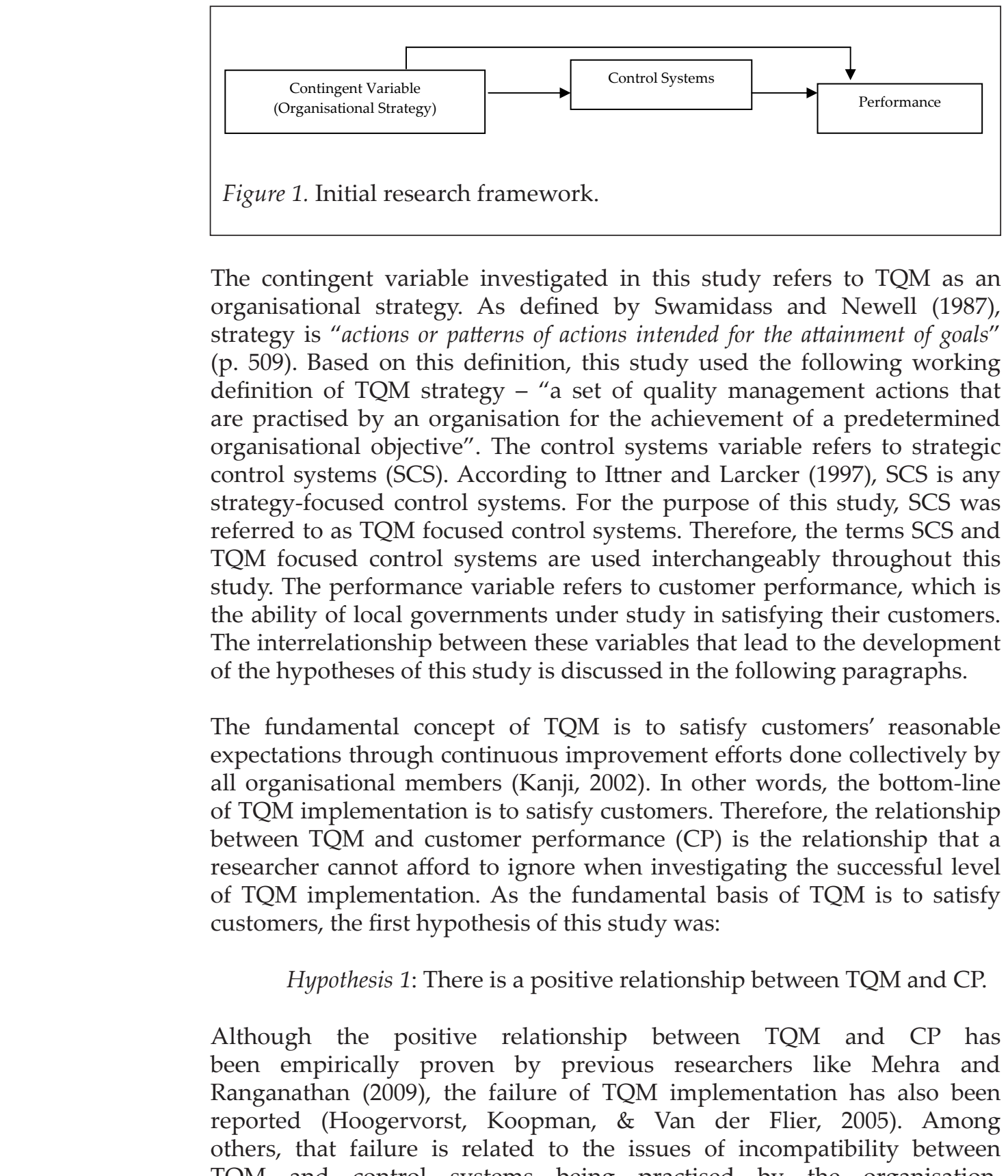

The contingent variable investigated in this study refers to TQM as an organisational strategy. As defined by Swamidass and Newell (1987), strategy is "actions or patterns of actions intended for the attainment of goals" (p. 509). Based on this definition, this study used the following working definition of TQM strategy - "a set of quality management actions that are practised by an organisation for the achievement of a predetermined organisational objective". The control systems variable refers to strategic control systems (SCS). According to Ittner and Larcker (1997), SCS is any strategy-focused control systems. For the purpose of this study, SCS was referred to as TQM focused control systems. Therefore, the terms SCS and TQM focused control systems are used interchangeably throughout this study. The performance variable refers to customer performance, which is the ability of local governments under study in satisfying their customers. The interrelationship between these variables that lead to the development of the hypotheses of this study is discussed in the following paragraphs.

The fundamental concept of TQM is to satisfy customers' reasonable expectations through continuous improvement efforts done collectively by all organisational members (Kanji, 2002). In other words, the bottom-line of TQM implementation is to satisfy customers. Therefore, the relationship between TQM and customer performance $(\mathrm{CP})$ is the relationship that a researcher cannot afford to ignore when investigating the successful level of TQM implementation. As the fundamental basis of TQM is to satisfy customers, the first hypothesis of this study was:

\section{Hypothesis 1: There is a positive relationship between TQM and CP.}

Although the positive relationship between TQM and $\mathrm{CP}$ has been empirically proven by previous researchers like Mehra and Ranganathan (2009), the failure of TQM implementation has also been reported (Hoogervorst, Koopman, \& Van der Flier, 2005). Among others, that failure is related to the issues of incompatibility between TQM and control systems being practised by the organisation. 
Several studies on the issues concerning the relationship between TQM and control systems have been reported in the management accounting literature (Daniel \& Reitsperger, 1991; Ittner \& Larcker, 1997). These studies were carried out based on the understanding that TQM, as a long-term strategy, requires a long-term perspective of control systems due to the fact that short-term perspective of control systems would hinder the attainment of TQM objectives. In an empirical study, Daniel and Reitsperger (1991) reported that the organisations used different control systems for different quality strategies. Among others, they found that manufacturing companies that adopt a zero-defect quality strategy had modified their control systems to encourage the continuous quality improvement. In another study, Ittner and Larcker (1997) found that there was a strong relationship between the practices of quality strategy and quality related control systems. The fit between strategy pursued and control systems being implemented is clearly important, since among the functions of control systems is to monitor the development of strategy implementation. Hence, the above elaboration has guided this research to arrive at:

Hypothesis 2: There is a relationship between TQM strategy and Strategic Control Systems (SCS).

The implementation of TQM into any organisation requires several changes on the control systems that are implemented by the organisation. The control systems, if accordingly developed, would be able to bring many positive consequences to the organisation. How do control systems bring positive effects on customer performance? Goold and Quinn (1993) using a case study approach found that the organisation with SCS would achieved higher performance. This was achieved due to the institutionalisation of SCS which had improved the clarity and realism of the organisational plan. With a clearer plan, the activities done by the organisation can attain better focus and the results would be more measurable. When the results are more measurable, then the resources of the organisation would be accordingly organised. The employees also would be willing to contribute more toward the betterment of the organisation, which in turn would lead to higher customer performance. Therefore, these arguments have led to the following hypothesis:

Hypothesis 3: There is a relationship between SCS and CP

\section{The Interrelationships between TQM, SCS, and CP}

Our second hypothesis clearly posited the relationship between TQM (where TQM as an independent variable) and SCS (as a dependent variable), and our

40 IJMS 17 (1), 37-53 (2010) 


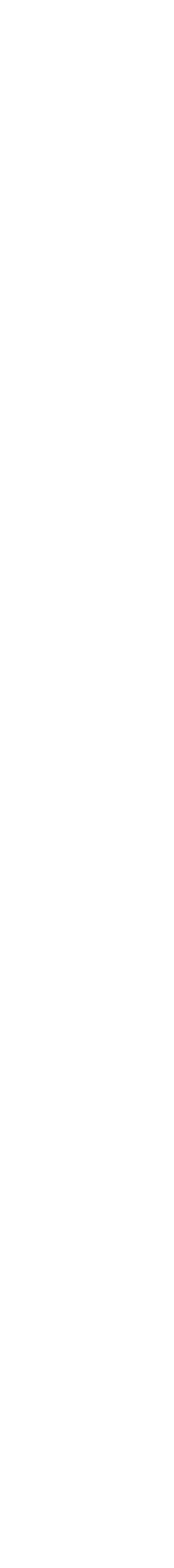

third hypothesis articulated the relationship between SCS (as independent variable) and $\mathrm{CP}$ (as dependent variable). These first and second hypotheses therefore, would lead us to consider the SCS as a mediating (intervening) ${ }^{1}$ variable between the TQM and $\mathrm{CP}$, and not as a moderating variable. Here, we present our discussion that would lead to the development of the fourth hypothesis. According to Herath (2007), the use of the suitable control systems is a prerequisite for any strategy to be implemented successfully. The implementation of TQM strategy, for example, cannot be separated from the organisational structure, like control systems (Othman, 2000), since the organisational control systems have an important role in supporting TQM implementation. As such, the function of the organisational control systems is to monitor the strategy development and implementation toward achieving the predetermined goals.

Therefore, the relationship between TQM and organisational performance is not restricted to the direct relationship, but could be indirect through the effect of SCS on customer performance. The link of TQM-SCS-CP is consistent with the literature that recognised the critical importance of SCS as monitoring and implementing systems of TQM (Andersen, Lawrie, \& Savic, 2004). This relationship is also in line with the concept of "fit as mediation" as proposed by Venkatraman (1989). This concept recognised "the existence of a significant intervening mechanism (e.g., organisational structure) between an antecedent variable (e.g., strategy) and the consequent variable (e.g., performance)" (Venkatraman, 1989, p.428). The relationship is perhaps relatively untapped in the previous literature. It explicitly considered the role of SCS on the relationship between TQM and customer performance. Therefore, this research hypothesised the following:

Hypothesis 4: The relationship between TQM and CP is mediated by SCS

\section{Research Framework}

In line with the initial research framework of this study as depicted in Figure 1, the following Structural Equation Modelling (SEM) model was developed. Figure 2 visualises the latent and observed variables of this study. Latent variables, namely TQM, SCS, and CP are represented by ovals. Observed variables, namely tqm1, tqm2, tqm3, tqm4, scs1, scs2, scs3, scs4, cp1, cp2, and cp3 are represented by the square shapes. The SEM model also accounted for random measurement error as represented by the small circles with the letter " $\mathrm{e}$ ". In this study, two-level SEM analysis was applied, where observed variables refer to items used to measure latent variables.

IJMS 17 (1), 37-53 (2009) 


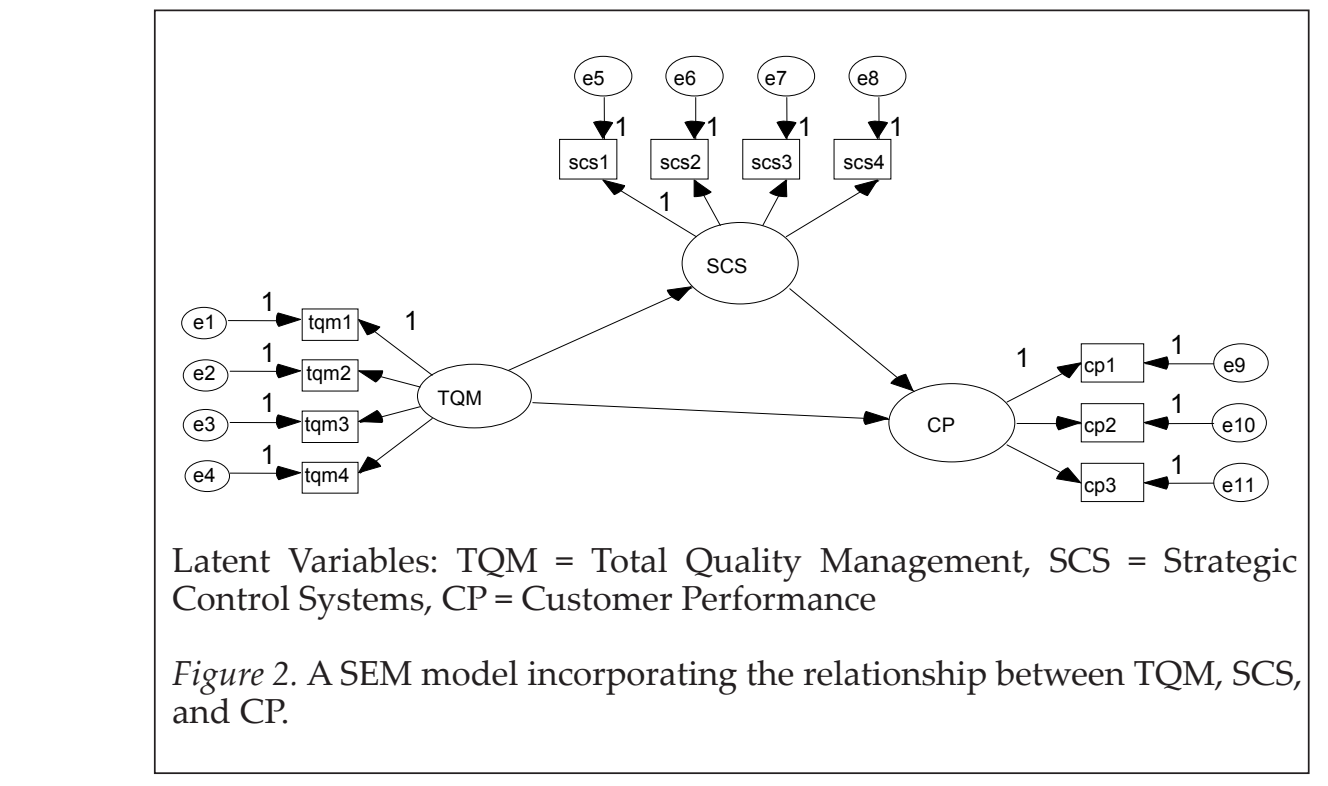

\section{Measurement}

All items were measured using interval scale and anchored on a five-point Likert scale, namely (1) for strongly disagree, (2) for somewhat disagree, (3) for neither agree nor disagree, (4) for somewhat agree, and (5) for strongly agree. An average score was calculated for each of the constructs based on

- its respective items. A higher score would indicate a higher practice of TQM, a more intense use of SCS, and a better CP.

Total Quality Management (TQM) was measured using four items as follows;

- TQM1 - commitment of top management on quality initiatives (Morsing \& Oswald, 2009);

- TQM2 - customer feedback is used effectively (Terziovski, 2006);

- TQM3 - engaged in extensive benchmarking practices (Terziovski, 2006); and

- TQM4 - quality related training is adequate (Terziovski, 2006).

Strategic Control Systems (SCS) was measured using five items derived from control systems literature as follows;

- SCS1 - TQM is translated into action that can be communicated (Ittner \& Larcker, 1997);

- SCS2 - linking rewards to TQM (Goold \& Quinn, 1993; Kaplan \& Norton, 1996);

- SCS3 - resource allocated based on TQM (Goold \& Quinn, 1993; Kaplan \& Norton, 1996); and

- SCS4 - activities not contributing to TQM objectives are eliminated (Kaplan \& Norton, 1996)

42 IJMS 17 (1), 37-53 (2010) 


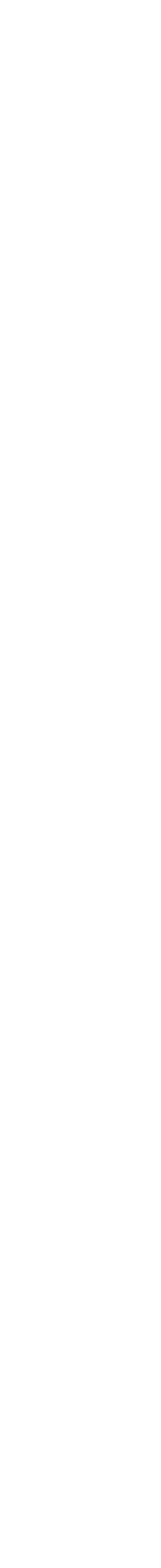

Customer Performance (CP) was measured using the three items as follows;

- CP1 - able to introduce new products to the customers timely (Weerakon, 1996);

- CP2 - increase the level of customer satisfaction (Mehra \& Ranganathan, 2009); and

- CP3 - have good reputation with their customers (Tippins \& Sohi, 2003).

\section{Data Collection}

The population of this study was restricted to the departments of City Councils (CC) and Municipal Councils (MC) in order to control the size of studied departments. The departments attached to the District Councils were excluded due to their smaller size as compared to the size of departments attached to the CCs and MCs. This control step was taken since previous study had revealed the significant differences in the relationship between TQM and organisational performance across different sizes of organisations (Gustafsson, Nilson, \& Johnson, 2003).

The pilot study was done to rectify the suitability of the questions. A total of 31 heads of department provided responses for the pilot study. As proven during the study, there was no evidence to indicate any misunderstanding, misinterpretation, or confusion of the items in the questionnaire set.

Table 1 tabulates the sampling frame of this study. As of 1st January 2008, there were 341 departments attached to 35 local governments. However 36 departments attached to four local governments, namely Kota Bharu Municipal Council (MC), Kuala Terengganu MC, Kajang MC, and Seremban MC were used for the pilot study, and so were removed from the sampling frame of the main study. Thus, the sampling frame contained of 305 departments attached to those 31 local governments.

Stratified cluster sampling was applied to this study due to the characteristics of intra-group heterogeneity and inter-group homogeneity of the local governments in Malaysia. All those local governments have similar functions, objectives, and roles as prescribed in the Local Government Act 1976, Town and Urban Planning Act 1976, and Road, Drainage, and Building Act 1974. However within each local government, there are various departments with different kinds of objectives, functions, and activities.

At the first stage, the local governments were stratified according to their status, either municipal or city council. At the second stage, all departments attached to city councils were selected due to the small number of departments involved. As illustrated in Table 1, there were 85 departments attached to city councils. A sample size of 250 was required for this study. This decision was taken due to the fact that the minimum sample size required to generate a valid model for SEM is 200 (Kelloway, 1998). Therefore, the resulting number, a total of $165(250-85)$ was selected from departments attached to municipal councils. The chosen municipal council was randomly selected 
as follows; (1) the researcher allocated a unique number for each local government; (2) the researcher wrote the number on a paper and shuffled it; (3) the researcher pulled out the papers one by one until a number of the desired sample size was adequate.

Table 1

Existing Departments of Local Governments in Peninsular of Malaysia

Local Governments Number of Existing Departments

City Council

Kuala Lumpur $\quad 22$

Johore Bharu

Alor Setar $\quad 8$

Malacca 13

Ipoh 9

Shah Alam 12

Petaling Jaya $\quad 14$

Municipal Council

Batu Pahat

Kluang 6

Muar 7

$\begin{array}{ll}\text { Sungai Petani } & 10\end{array}$

Kulim 10

Langkawi $\quad 8$

Kota Bharu $\quad 8$

Alor Gajah $\quad 11$

Seremban $\quad 11$

Nilai 6

Port Dickson $\quad 9$

Kuantan 11

Temerloh 13

Manjung 10

Taiping 8

Kuala Kangsar $\quad 7$

$\begin{array}{ll}\text { Teluk Intan } & 8 \\ \text { Kangar } & 8\end{array}$

Pulau Pinang $\quad 10$

- Seberang Prai 10

Ampang Jaya

Kajang 10

Klang 10

Selayang 11

Subang Jaya $\quad 9$

$\begin{array}{ll}\text { Sepang } & 7\end{array}$

K. Terengganu

Kemaman 6

Total population 341

Source. Developed by researcher based on information of every local government.

$44 \quad$ IJMS 17 (1), 37-53 (2010) 


\section{Data Analysis}

Table 2 reports the distributed and returned questionnaires. Out of 250 questionnaires distributed, 205 were returned and usable for further analysis. The following paragraph discusses the results of unidimensionality and reliability tests. The first step in the statistical procedure that needs to be undertaken in order to test the construct validity is unidimensionality (Anderson \& Gerbing, 1988). Unidimensionality is the condition that must be satisfied before assessing the reliability of the construct (Dunn, Seaker, \& Waller, 1994). It refers to the existence of one construct underlying a set of items (Dunn et al., 1994). Two techniques, namely item-construct correlation and exploratory factor analysis, were performed to test the unidimensionality of the constructs, and the results of which are reported in Table 3 and Table 4.

Table 2

The number of Questionnaires Distributed and Returned (number=205)

\begin{tabular}{|c|c|c|c|}
\hline Local Government & Distributed Questionnaire & Returned and Usable & Percentage (\%) \\
\hline \multicolumn{4}{|l|}{ City Hall/Councils } \\
\hline Kuala Lumpur & 22 & 14 & 63.64 \\
\hline Johor Bharu & 7 & 6 & 85.71 \\
\hline Alor Setar & 8 & 5 & 62.50 \\
\hline Melaka & 13 & 10 & 76.92 \\
\hline Ipoh & 9 & 9 & 100.00 \\
\hline Shah Alam & 12 & 10 & 83.33 \\
\hline Petaling Jaya & 14 & 12 & 85.71 \\
\hline \multicolumn{4}{|l|}{ Municipal Council } \\
\hline Batu Pahat & 6 & 5 & 83.33 \\
\hline Johor Bharu Tengah & 9 & 8 & 88.89 \\
\hline Muar & 7 & 5 & 71.43 \\
\hline Sungai Petani & 10 & 8 & 80.00 \\
\hline Kulim & 10 & 8 & 80.00 \\
\hline Langkawi & 8 & 7 & 87.50 \\
\hline Alor Gajah & 11 & 9 & 81.82 \\
\hline Port Dickson & 9 & 7 & 77.78 \\
\hline Kuantan & 11 & 10 & 90.91 \\
\hline Temerloh & 13 & 10 & 76.92 \\
\hline Kuala Kangsar & 7 & 6 & 85.71 \\
\hline Kangar & 8 & 7 & 87.50 \\
\hline Pulau Pinang & 10 & 8 & 80.00 \\
\hline Seberang Prai & 10 & 10 & 100.00 \\
\hline Ampang Jaya & 10 & 8 & 80.00 \\
\hline Klang & 10 & 8 & 80.00 \\
\hline Subang Jaya & 9 & 9 & 100.00 \\
\hline Kemaman & 7 & 6 & 85.71 \\
\hline Total & 250 & 205 & 82.00 \\
\hline
\end{tabular}

IJMS 17 (1), 37-53 (2009) 45 
Table 3 tabulates the results of item-construct correlations. The results showed that the assigned items have the highest correlation with the construct they intended to measure when compared to the other constructs. In other words, it was proven that these items had been correctly assigned to the construct they intended to measure. Table 3.0 reports the results of the Cronbach coefficient alpha for the scales of the study. As depicted, the Cronbach coefficient alpha for all measures surpassed the suggested level of 0.7 (Nunnaly, 1978). From further analysis, the value of Cronbach alpha of constructs tested appeared to be decreasing if any of the items were deleted. In other words, all items attached to the related construct were important for having a construct with high internal consistency.

Table 3

Reliability Tests

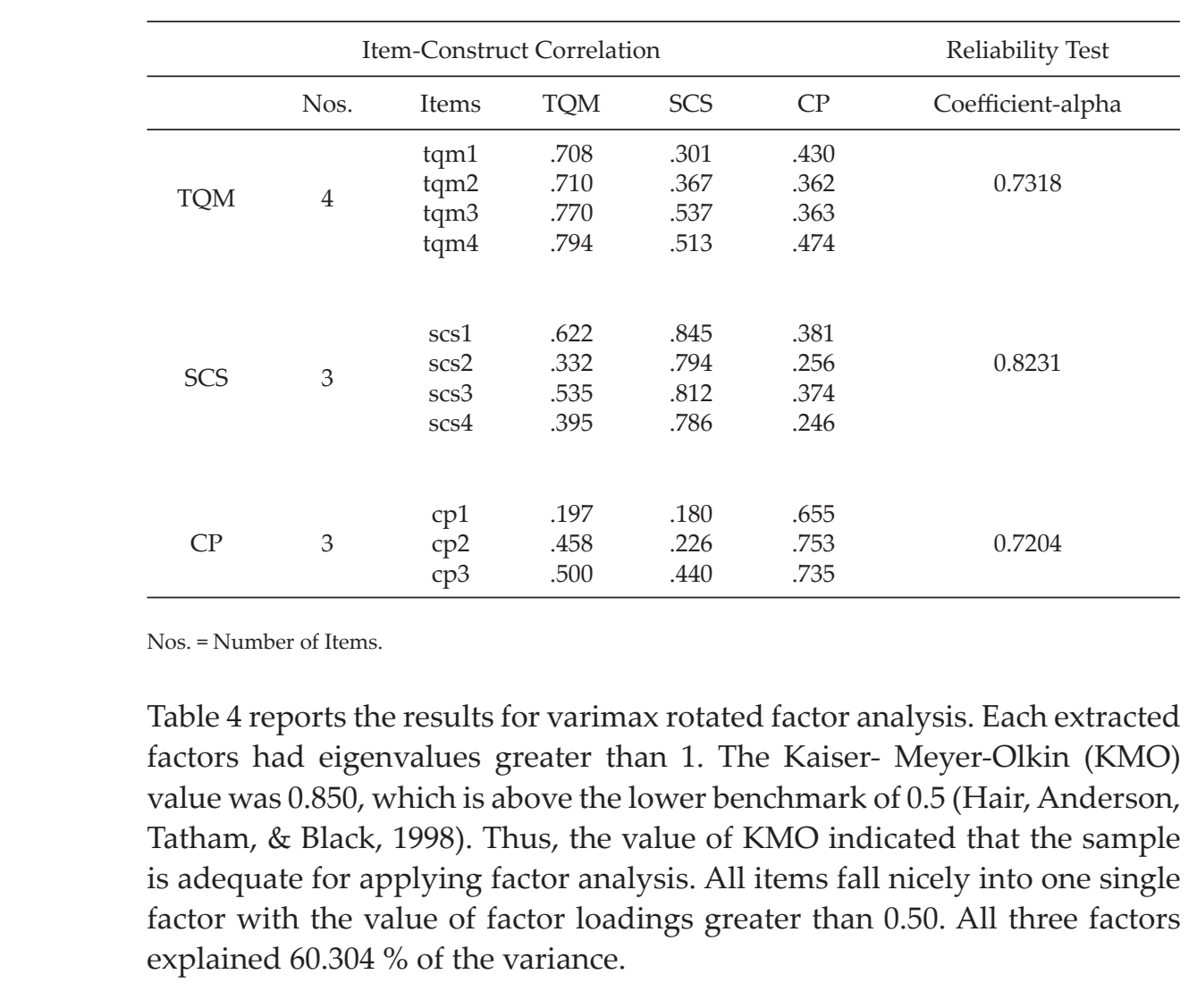

46 IJMS 17 (1), 37-53 (2010) 
Table 4

Factor Analysis

\begin{tabular}{lccccc}
\hline Constructs & Nos. & $\begin{array}{c}\text { Factor } \\
\text { Loading }\end{array}$ & Eigenvalue & $\begin{array}{c}\text { \% of Variance } \\
\text { Explained }\end{array}$ & $\begin{array}{c}\text { Cumulative } \\
\text { Variance Explained }\end{array}$ \\
\hline TQM & 4 & $0.584-0.657$ & 4.819 & 40.156 & 40.156 \\
SCS & 3 & $0.605-0.807$ & 1.307 & 10.896 & 51.052 \\
$\mathrm{CP}$ & 3 & $0.578-0.732$ & 1.110 & 9.252 & 60.304 \\
\hline \multicolumn{5}{l}{$\mathrm{KMO}=0.850 ;$ Bartlett's Test of Sphericity (chi square $=903.06 ; \mathrm{p}<0.01)$} \\
\hline
\end{tabular}

Nos. $=$ Number of Items .

\section{Research Findings}

The values of skewness and kurtosis indicated that the data were normally distributed. The assumption of normality of data is prerequisite before the use of maximum likelihood estimation by SEM can be performed. Prior to testing the hypotheses of the study, the model's overall index must be established (Bollen, 1989). The result of the structural model with standardised parameter is presented in Figure 3. Based on the three indices, namely Goodness of Fit Index (GFI), Incremental Fit Index (IFI), and Comparative Fit Index (CFI), the model surpassed the suggested thresholds, thus this would indicate that the model was acceptable. According to the results, the chi-square value of 1.56 with 71 degrees of freedom and the $p=0.212$ was insignificant at $p \geq 0.05$. The insignificant value of chi-square indicated the model fits with the data (Hair et al., 1998).

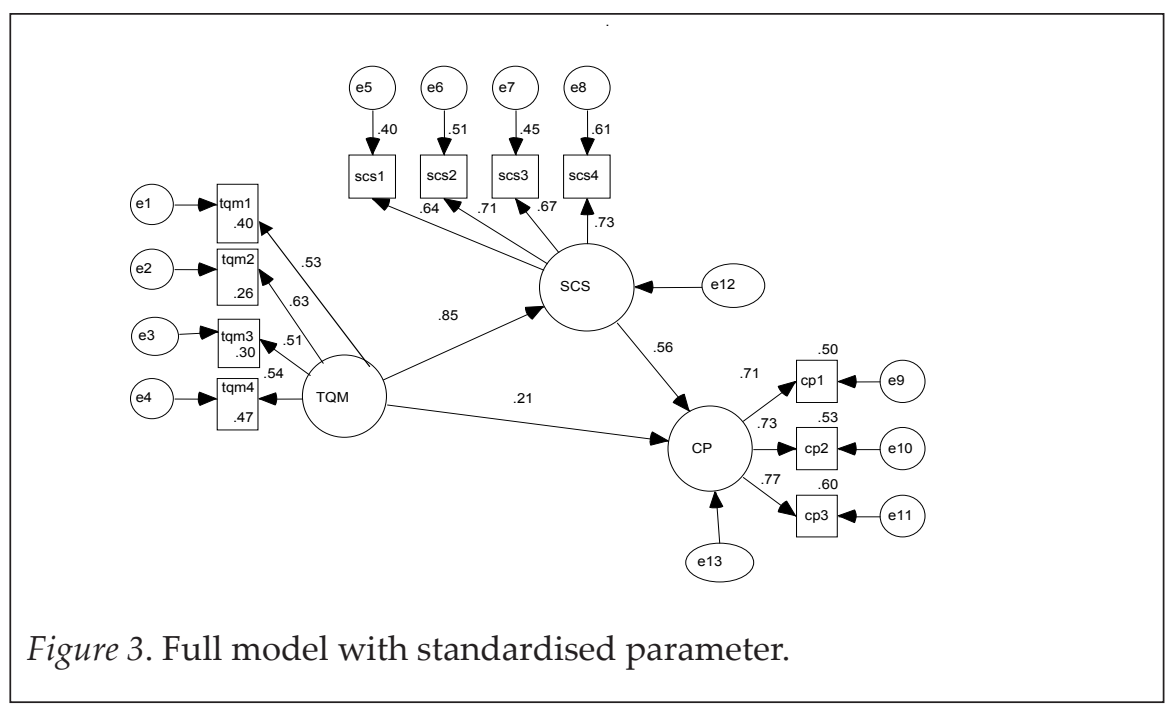


Table 5.0 shows that the path TQM-SCS and SCS-CP are statistically significant with the values of Critical Ratio (CR) exceeding 1.96 (Arbuckle \& Worthe, 1999). In other words, $\mathrm{H}_{2}$ and $\mathrm{H}_{3}$ were supported. The path TQM-CP was statistically insignificant. Thus $\mathrm{H}_{1}$ was not supported. The mediating role of SCS in explaining the relationship between TQM and CP was evaluated based on the direct and indirect effect value. As tabulated, the total effect of TQM-CP was 0.688 , which is higher than the direct effect of TQM on CP, which was 0.211 . In other words, the effect of TQM on CP is indirect and the link is mediated by CS. Thus, $\mathrm{H}_{4}$ was supported.

Table 5

Hypotheses Testing

\begin{tabular}{lcccllll}
\hline & \multicolumn{3}{c}{ Index of Full Model } & \multicolumn{3}{c}{ Standardised Direct/Indirect Effect } \\
\hline Indices & Value & Threshold & Acceptability & Path & Direct & Indirect & Total \\
\hline GFI & 0.908 & $\geq 0.90$ & Acceptable & TQM-SCS & 0.850 & nil & 0.850 \\
IFI & 0.908 & $\geq 0.90$ & Acceptable & TQM-CP & 0.211 & 0.477 & 0.688 \\
CFI & 0.906 & $\geq 0.90$ & Acceptable & SCS-CP & 0.561 & nil & 0.561 \\
\hline \multicolumn{7}{c}{ Hypotheses Testing } \\
\hline Path & S.E. & s.e. & CR $^{*}$ & Hypothesis & Results \\
\hline TQM-CP & 0.211 & 0.425 & 0.487 & $\mathrm{H}_{1}$ & not supported \\
TQM-SCS & 0.850 & 0.231 & $3.688^{*}$ & $\mathrm{H}_{2}$ & supported \\
SCS-CP & 0.561 & 0.276 & $2.039^{*}$ & $\mathrm{H}_{3}$ & supported \\
\hline
\end{tabular}

Notes. GFI = Goodness of Fit Index, IFI = Incremental Fit Index, CFI = Comparative Fit Index, S.E. = standard estimate, s.e. $=$ standard error, $C R=$ Critical Ratio, ${ }^{*}$ significant at $C R \geq 1.96$.

\section{Discussion and Implications}

The insignificant path of TQM-CP provided an interesting finding due to this result being inconsistent with most studies, like Kanji (2002), where many researchers had concluded TQM as an important predictor of customer satisfaction. However, not all implementers of TQM were able to successfully execute the strategy. By looking at the scenario surrounding the local governments in Malaysia, the link between TQM and performance achieved by them is questionable. Based on the fact the quality awareness has been implemented in Malaysian local governments since 1989, the situation of receiving much criticism and complaints from the constituents should already be a thing of the past. However, according to Ibrahim and Abd Karim (2004), Malaysian local governments still receive much criticism and complaints, suggesting the inability of the Malaysian local governments in delivering good services to meet the needs of their constituents. Thus, this finding is another report to support the non-existence of the simple direct link between TQM and customer performance.

48 IJMS 17 (1), 37-53 (2010) 


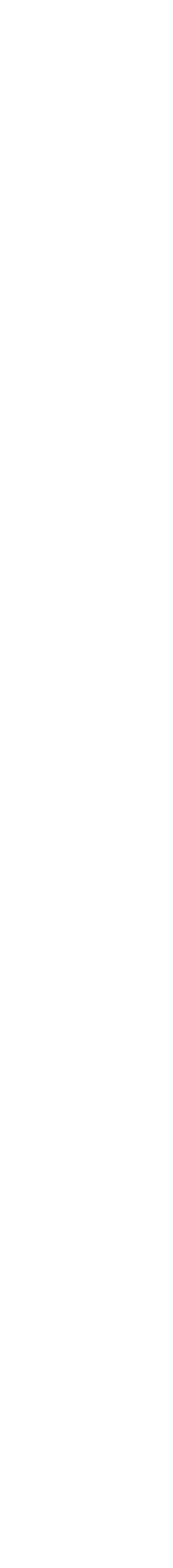

The significant path of TQM-SCS supported the premise of the contingency theory that suggests the control systems practiced should be aligned with the strategy pursued by an organisation. Previous study (Herath, 2007; Chenhall, 2003) also supported the above theory. In Herath's study, he discovered that organisations must design control systems in accordance with the requirements of the strategy pursued by them. Therefore, this study concluded that the higher the level of TQM being implemented, the higher would be the level of SCS being used. Another researcher, Chenhall (2003), found that SCS had been recognised as important systems for monitoring and implementing organisational strategy. Therefore, for those organisations that are in the process of designing their control systems, it must be co-aligned with their intended strategy. Among the critical elements of control systems that need attention from the managers are the target settings, evaluation process, measuring the performance, reward systems, and feedback management. The practice of all these elements should always be consistent with the intended goal of strategy in order to provide adequate support for the strategy implementation. If the organisation fails to do so, perhaps, the practice of these elements would not only be inconsistent with the requirements of strategy, but also may hinder the achievement of the formulated objectives. For instance, the practice of budget control systems should not only focus on the quantitative objective, such as number of outputs, but also need to consider to qualitative objectives, such as quality of products. By having this, employees would know what to focus on and how they would be rewarded by the organisation.

The significant path of SCS-CP supported the proposition that the implementation of control systems would bring positive effects to the organisations, including achieving their strategic target. This finding provides evidence that the control systems as essential systems to plan, monitor, measure, and evaluate the implementation of customer related strategies. Although much has been said about the success of TQM as a customer related strategy (Mehra \& Ranganathan, 2009), a good strategy alone is inadequate to secure good benefit. More importantly, a good strategy must be accomplished and monitored by strategically tailored control systems (Herath, 2007; Modell, 2009). This is because the implementation of a good strategy like TQM is not free from employee resistance (DahlgaardPark, 2008) and thus this obstacle must be systematically handled.

The higher effect of TQM on CP through SCS as compared to the direct effect of TQM on CP provided support for the usefulness of having suitable control systems. Control systems, among others are implemented with the purpose to track the development of TQM implementation as well as to internalise the objectives of TQM being implemented into the hearts of all organisational members. To assure TQM is successfully implemented, the 
managers play an essential role in inspiring people under their supervision to focus on the attainment of strategy pursued. This role can effectively be played by managers due to the existence of control systems, which would benefit managers in controlling the action of other organisational members (Morsing \& Oswald, 2009).

TQM needs high inter-functional activities whereby entire functional activities like research and development, purchasing, production, human resource, accounting, and marketing are involved in the attainment of TQM - strategy. These high inter-functional activities need to be coordinated, and this role can be effectively played by control systems. Therefore, the results suggested that local governments seeking to improve their performance by practising TQM are subject to the presence of TQM focused control systems. By having TQM focused control systems, TQM would be easier to be internalised by all organisational members as a way of life, since among the function of control systems is to align the personal objectives of each employee with the objective that is being targeted by the organisation.

\section{Limitations of The Study}

As with other scientific research, this study was not without limitation. Two important limitations that need to be addressed are, namely sample size and the use of single informants. Although the sample size of 205 was considered adequate for the structural analysis to be valid, a bigger sample size would be able to provide a more stable model. This study also used single informants to respond to the independent and dependent variables. The use of single informants may lead to some systematic bias, even though the data collection process was carefully implemented.

\section{Conclusion}

무

It is undeniable that the TQM is a significant determinant of customer satisfaction, but this paper goes beyond the said premise by signifying the role of SCS. It has reported that SCS is a mediator variable between the TQM and $\mathrm{CP}$ variables and it is the systems that monitored the implementation of TQM. The implementation of TQM requires a long process and involves a concerted effort from all members, where the entire progress of TQM must be carefully monitored. Therefore, with the presence of suitable control systems, a local government would be more effective in monitoring and evaluating the attainment of TQM objectives. In short, this paper has provided some significant support that control systems is a main factor for TQM to be successfully implemented.

$50 \quad$ IJMS 17 (1), 37-53 (2010) 


\section{End Note}

1. A dependent variable is directly caused by an independent variable. An intervening (mediating) variable is caused by an independent variable and causes a dependent variable. A moderator variable affects the relationship between an independent and dependent variable, but does not have a bivariate relationship with either the dependent or independent variables (Shields, Deng, \& Kato, 2000, p.185).

\section{References}

Andersen, H.V., Lawrie, G., \& Savic, N. (2004). Effective quality management through third generation balanced scorecard. International Journal of Productivity and Performance Management, 53(7), 634-645.

Anderson, J.C., \& Gerbing, D.W. (1988). Structural equation modeling in practice: A review and recommended two step approach. Psychological Bulletin, 103(3), 411-423.

Banker, R.D., Potter, G., \& Schroeder, R.G. (1993). Reporting manufacturing performance measures to workers: An empirical study. Journal of Management Accounting Research, 1(5), 33-55.

Bollen, K.A. (1989). Structural equations with latent variable. New York: Wiley.

Chenhall, R.H. (2003). Management control systems design within its organizational context: Findings from contingency-based research and directions for the future. Accounting, Organisations and Society, 28, 127-168.

Dahlgaard-Park, S.M. (2008). Reviewing the European excellence model from a management control view. The TQM Journal, 20(2), 98-119.

Daniel, S.J., \& Reitsperger, W.D. (1991). Linking quality strategy with management control systems: Empirical evidence from Japanese industry. Accounting, Organisations and Society, 16(7), 601-618.

Dunn, S.C., Seaker, R.F., \& Waller, M.A. (1994). Latent variables in business logistics research: Scale development and validation. Journal of Business Logistics, 15(2), 145-172.

Ehigie, B.O., \& McAndrew, E.B. (2005). Innovation, diffusion, and adoption of total quality management (TQM). Management Decision, 43(6), 925940.

Goold, M., \& Quinn, J.J. (1993). Strategic control: Milestones for long-term performance. London: Pitman Publishing.

Gustafsson, A., Nilsson, L., \& Johnson, M.D. (2003). The role of quality practices in service organisations. International Journal of Service Industry Management, 14(2), 232-244.

Hair, J.F., Anderson, R.E., Tatham, R.L., \& Black, W.C. (1998). Multivariate data analysis, (5th ed.) USA: Prentice Hall. 
Herath, S.K. (2007). A framework for management control research. Journal of Management Development, 26(9), 895-915.

Hoogervorst, J.A.P., Koopman, P.L., \& Van der Flier, H. (2005). Total quality management: The need for an employee-centred coherent approach. The TQM Magazine, 17(1), 92-103.

Ibrahim, F.W., \& Abd. Karim, M.Z. (2004). Efficiency of local governments in Malaysia and its correlates. International Journal of Management Studies, 11(1), 57-70.

Ittner, C.D., \& Larcker, D.F. (1997). Quality strategy, strategic control systems and organizational performance. Accounting, Organizations and Society, 22(3/4) 295-314.

Kanji, G.K. (2002). Measuring business excellence. Routledge advances in management and business studies. london: Routledge.

Kaplan R.S., \& Norton, D.P. (1996). The balanced scorecard. Translating strategy into action. Boston: Harvard Business School Press.

Kelloway, E.K. (1998). Using LISREL for structural equation modelling: A researcher's guide. California, USA: Sage Publications.

Othman, R. (2000). Contingencies of quality management approach: Evidence from the manufacturing sector. Utara Management Review, 1(2), 57-68.

Mehra, S., \& Ranganathan, S. (2009). Implementing total quality management with a focus on enhancing customer satisfaction. International Journal of Quality \& Reliability Management, 25(9), 913-927.

Modell, S. (2009). Bundling management control innovations. Accounting, Auditing, \& Accountability Journal, 22(1), 59-90.

Moores, K., \& Chenhall, R.H. (1994). Framework and MAS evidence (in) Strategic management accounting: Australasian cases. (Eds). Mores, K. Brisbane: John Wiley.

Morsing, M., \& Oswald, D. (2009). Sustainable leadership: Management control systems and organizational culture in Novo Nordick A/S, Corporate Governance, 9(1), 83-99.

Nunnaly, J.C. (1978). Psychometric Theory. New York: McGraw Hill.

Shields, M.D., Deng, F.J., \& Kato, Y. (2000). The design and effects of control systems: Tests of direct and indirect effects models. Accounting, Organisations, and Society, 25, 185-202.

Swamidass, P.M., \& Newell, W.L. (1987). Manufacturing strategy, environmental uncertainty and performance: A path analytic model. Management Science, 33(4), 509-524.

Terziovski, M. (2006). Quality management practices and their relationship with customer satisfaction and productivity improvement. Management Research News, 29(7), 414-424.

Tippins, M.J., \& Sohi, R.S. (2003). It competency and firm performance: Is organizational learning a missing link, Strategic Management Journal, $24,745-761$.

52 IJMS 17 (1), 37-53 (2010) 
Venkatraman, N. (1989). The concept of fit in strategy research: Toward verbal and statistical correspondence. Academy of Management Review, 14(3), 423-444.

Weerakon, T.S. (1996). Organizational performance - A stakeholder concept. Proceedings of International Research Conference on Quality Management, 80-90. 


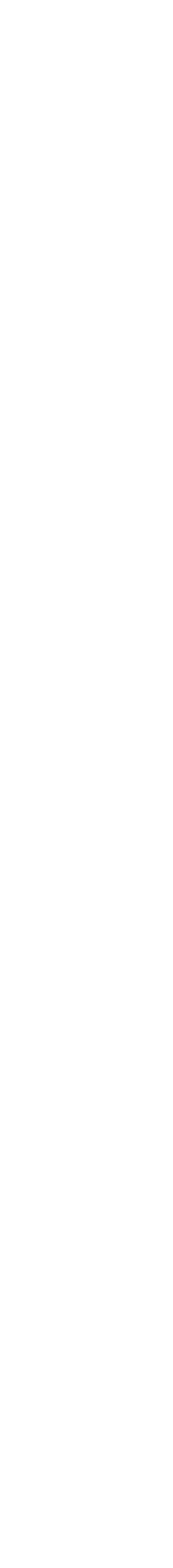

